\title{
An Evaluation of How Student Expectations Are Formed in a Higher Education Context: The Case of Hong Kong
}

\author{
Mike Willis \\ Rowan Kennedy
}

\begin{abstract}
This research identifies a range of issues and factors which impact on the formation of initial expectations developed by local university students wishing to study for a foreign degree program in Hong Kong. Key factors were foreign university Internet sites, exhibitions, agents and associations, brochures and friends. This is one of the first times this kind of research has been undertaken relating to the delivery of foreign programs within the home country, as previous research has tended to focus on study abroad, where the student travels to the foreign country to undertake a degree program. The research also considers how expectations change over time, as students undertake their study for a foreign degree program in Hong Kong, and develops the concept of continuous formation of expectations whereby students mould change, rebuild and continually revisit their expectations of the university program as they undertake a wide range of subjects. This part of the research is quite new and indicates the volatile and changeable nature of the educational service encounter. Both parts of the research are of value not just in regard to the location of the data collection but potentially further afield as an indicator of formative factors regarding expecta-
\end{abstract}

Mike Willis, PhD, is Lecturer in Marketing, Monash University, Switchback Road, Churchill, Victoria 3842 Australia.

Rowan Kennedy is affiliated with the Marketing Department, Monash University, Switchback Road, Churchill, Victoria 3842 Australia.

Journal of Marketing for Higher Education, Vol. 14(1) 2004

http://www.haworthpress.com/web/JMHE

(C) 2004 by The Haworth Press, Inc. All rights reserved.

Digital Object Identifier: 10.1300/J050v14n01_01 
tions and in regard to the concept of continuous formation of expectations. [Article copies available for a fee from The Haworth Document Delivery Service: 1-800-HAWORTH. E-mail address: <docdelivery@haworthpress. com> Website: <http://www.HaworthPress.com> () 2004 by The Haworth Press, Inc. All rights reserved.]

KEYWORDS. Study abroad, formation of expectations, customer satisfaction, services marketing

\section{INTRODUCTION}

A considerable body of research has been undertaken into the issue of study abroad-that is, where students travel overseas to study in a foreign educational institution. Most commonly, study abroad takes place at the university level.

Marketing issues associated with this area of research typically focus on choice of foreign university and experience of university life in the foreign country, while less attention has been placed on the delivery of foreign programs in the student's home country where, for example, the foreign university (such as Monash University in Australia) delivers a program in the student's home country (such as Hong Kong). However, initial research undertaken by Willis and Rushdi (2000) indicated the scale extent and importance of this form of educational delivery.

One key aspect of foreign university delivered programs in the home market (such as Hong Kong) is the issue of how students form their expectations about the foreign university program. A second related issue is whether these expectations change over time as students undertake their university studies. The former issue has received some attention from the perspective of study abroad (where the student travels to the foreign country), but less so in terms of the delivery of the foreign program in their home country, but the latter issue has received negligible attention.

The aim of this paper is to identify the factors which influence initial formation of expectations, and secondly, to identify whether respondents, in this case students enrolled in a foreign program delivered in Hong Kong, felt that their expectations changed over time. Hong Kong has been chosen because it is one of the busiest of all locations for foreign degree programs delivered within the Special Administrative Region.

The findings will help foreign universities in a wide range of locations, and conceivably, not just delivering programs in Hong Kong, to better identify the various sources of formation influence (which might enable them to modify 
their promotional and associated marketing programs), and, secondly, might enable them to better understand the nature of expectation change over timewhether expectations change and if so, why.

\section{LITERATURE REVIEW}

As mentioned earlier, and in regard to the issue of formation of student expectations, study abroad has long been the focus of attention by higher education researchers, who have identified a plethora of key factors influencing the choice of foreign educational institution (for example, Rao, 1979; Austin, 1988; Molla and Sedlacek, 1989; Wu, 1989; Bromilow and Zubrzycki, 1990; Steadman and Dagwell, 1990; and Stewart and Felicetti, 1991). Research by Lawley (1993) culminated in a framework of 19 specific factors that were subsequently grouped into several categories by Lawley and Perry (1998). These somewhat broad and general approaches to students' selection of foreign education providers, however, did not examine particular study abroad issues such as social and lifestyle experiences. Research undertaken by Hausler, Sharma and Sivagnanam (1995) and Wilkinson (1995) addressed this aspect in their identification of specific challenges and special needs of foreign (particularly Asian) students. And, more recently, Kennedy, Willis and Rushdi (2000), in their study, found that, in general, the expressed expectations of Singaporean students regarding Australian university education standards and facilities were not met.

There are two gaps in this literature. Firstly, it does not evaluate the formation of expectations regarding foreign university programs delivered in the students' home country. Secondly, it does not identify in detail how expectations are formed. Do they emanate from friends, family, other students, or less direct influences such as the image of the foreign country?

The first aim of this research is to provide an answer to these questions, in the context of foreign delivered programs in Hong Kong.

A further aspect of the research topic is the longevity of educational study and whether expectations might be changed and moulded over time. One theory (not particularly related to education, though) is that of Hoer and Macinnes (2001), which suggests that expectations can at least be confirmed or disconfirmed over time, but their model is not particularly relevant to education, and it is not very detailed. However, their model does indicate that expectations can be changed (in the postive and negative) over time and it is a useful example of how consumer experience of a product or service can modify their intial view.

Other studies have also considered what happens when expectations are formed and then not met because of poor service or associated factors. Usu- 
ally, customers become edgy and move elsewhere to try a new service provider or product manufacturer (Tannenbaum, Mathieu, Salas and CannonBowes, 1991; Wanous, Poland, Premack and Davis, 1992; Kennedy, 2001). It is not clear from these studies, however, what happens in an educational setting where students might find it rather more difficult to move somewhere else, since they typically study for their degree over several years.

The customer service literature has also considered the issue of what happens if expectations are not met but it has tended to focus on short-term service and/or product encounters (Churchill and Suprenant, 1982; Johnson and Fornell, 1991; Anderson and Sullivan, 1993). None of these studies consider a long term service encounter such as educational study.

In regard to the educational field, there has been some study of what happens if student expectations are not met. For example, a study by Kennedy, Willis and Rushdi (2000), of Singaporean students, found that many students felt their expectations were not met. In this situation, they tended to complete their degree (often under some degree of sufferance) and then transfer to another university for further study. The problem with this research in regard to the present topic is that it once again focuses on study abroad, and also does not probe in detail the process by which initial expectations changed, moulded and perhaps reformed over time-rather the research simply noted that initial expectations (which were itemised) were often not met.

Therefore, there is another gap here to identify how expectations might actually change over time, in terms of an educational service encounter. This issue will be considered once again in the context of students studying for a foreign degree in their home country.

Finally, it is necessary to define the term expectations before proceeding any further. Expectation is generally acknowledged as a difficult and complex construct for which reliable and valid measures do not currently exist. In fact, it has been suggested that expectations be excluded from future customer satisfaction models (Kristensen, Martensen and Gronholdt, 1999) due, in part, to the difficulty of achieving reliable and valid measures. In recognition of this challenge, indicators have been developed and tested in the present study for these unobservable, latent variables that require identification and measurement in the milieu of foreign education provision.

For the purpose of the present study, expectations are defined as: $a$ preconsumption belief about the future performance of the service provided by a foreign university. 


\section{METHODOLOGY}

The sample used in this study consisted of 110 tertiary students in Hong Kong who were studying in foreign degree programs in Hong Kong or abroad. These students completed a self-report questionnaire distributed in class, 97 of which were found to be useable.

The method for gathering data was a two-stage process as follows:

\section{Stage 1}

The items were measured by means of a 35-item scale developed for the research. A 5-point Likert scale was used with 1 indicating "not important" and 5 indicating "very important," with a mid-point of "neither important nor unimportant." Thus, the scale positions above 3 indicate a positive response to the item (such as "importance of family"), while those below 3 indicate a level of disagreement.

Results were processed using Statistical Package for Social Sciences (SPSS) Version 10.

This stage was designed to identify the sources of expectation formation for students regarding their choice of foreign university.

\section{Stage 2}

Stage 2 was more complex and was based on a series of open ended face-to-face individual interviews conducted with 42 Hong Kong students subsequent to the distribution of the questionnaire. This stage was designed to discuss in more detail the items raised in the questionnaire, and, secondly, to identify whether students felt that their expectations changed over time as they studied for their university degree-and if so, in what way. In a sense this part of the research process was somewhat more exploratory, and certainly more open ended than Stage 1. This process was designed around qualitative methodological processes identified by Lewin et al. (1990).

Both stages were conducted in Hong Kong in late 2000 and, on the basis of some of the Stage 2 findings, were augmented by Australian-based interviews with Hong Kong students undertaking university programs in Australia.

\section{DISCUSSION AND ANALYSIS OF THE DATA}

\section{Part A: Formation of Expectations}

The Appendix provides summary statistics regarding the factors which formed expectations. This section discusses individual items on the question- 
naire and is supplemented with additional comments received via qualitative focus group meetings with the students.

\section{Family Influences}

Family in Hong Kong (mean of 3.93) was seen by students to be an important influencing factor, although it was not considered to be crucial. For example, students indicated that they would not simply follow the views of their parents, as most of them constructed their views and expectations about study at a foreign university through a more complex network of influences, rather than just their family.

Students admitted, however, that if their parents had strong negative views about a particular foreign university (which was almost never the case), this would influence them more than if the family had neutral or slightly positive views about one or a number of foreign universities.

Family abroad (which is family of the respondent living and working abroad) ranked slightly lower (mean 3.87), but this lower ranking is slightly misleading. Students explained that although family living abroad were, once again, not seen to be a crucial or a key influencing factor, they would often receive valuable information, advice and assistance from them when deciding about studying in that country. This advice was not so important when studying for the foreign degree in Hong Kong. Therefore, the importance of family abroad varied according to the mode of study.

It can be concluded that the role of family in Hong Kong and abroad was important in helping students to develop their views and expectations about foreign universities. They were not the only formulating influence, however; they were usually seen as one of a number of influencing factors contributing to the development of views and expectations about a particular foreign university. Nevertheless, students indicated that they would never actively go against negative views expressed by family members. This conforms to the role of the Chinese family as noted by Harris and Moran (1981), for example, as being of particular importance in decision making. It was surprising that the family did not rank slightly higher in view of the role of family members, especially parents, in Chinese society.

\section{Friends}

The item friends in Hong Kong ranked quite highly (mean 3.96) but was viewed as less important than friends abroad (mean 4.02) and, in particular, friends who had studied abroad (mean 4.07). Friends abroad may not have studied in the overseas location but were of some influence because, respon- 
dents felt, they would at least have some knowledge of foreign universities and what they were like. (Also, respondents felt that they would be more worldy than their Hong Kong counterparts and understand the ethos and nature of foreign, and particularly western universities.) However, friends who had studied abroad were of most value to respondents. This was because they could report back on the actual quality of particular foreign universities. Respondents felt that if their friends who had studied abroad felt that a particular foreign university was good, this was a good indicator that they should expect an equivalent standard in Hong Kong, even though these friends had, by definition, studied abroad and not in the Hong Kong based foreign program.

One of the most curious (and unexpected) findings of this research was the rather low mean score for brothers and sisters who had studied abroad (mean 3.11). One might have predicted that these siblings would have a significant impact on the formation of expectations about foreign universities, but the mean was lower than that for friends. This was for several reasons: some students felt that friends (abroad/in Hong Kong) were more objective than brothers and sisters and some indicated a level of rivalry between siblings. Others indicated that the key issue was that friends were usually at the same age/peer level compared with older or younger brothers and sisters, and therefore were more relevant in terms of information sources.

\section{Colleagues}

The potential influence of colleagues in the workplace was tested, but found to rank quite low (mean 2.21), and was usually dismissed in discussion. This was despite the fact that a significant percentage of students were working in Hong Kong, and cited work reasons as a key driver for study in a university program.

In almost every case, however, students felt that the views of work colleagues were of little value in forming expectations about foreign universities. Several reasons were cited: frequently, colleagues had not studied at a foreign university, and some were seen as possible competitors so they were deliberately not consulted about degree programs. More particularly, though, many students indicated that the issue of study was a private one and should not be discussed with general colleagues-that is, it was considered a deeply personal issue and not one to be discussed in the lunchroom. This comment was made on many occasions, and tends to support the importance of education in China and Hong Kong for individual personal development. Students did feel that higher education had intrinsic value and importance in addition to its ability to assist them to achieve higher ranking positions in the competitive Hong Kong job market. 


\section{Government Bodies}

The impact of government bodies on the formation of expectations was evaluated using two items on the questionnaire. The government bodies fell into two categories: Hong Kong-based bodies (including the various educational bodies such as the Education Commission and the University Grants Commission), and international Government bodies, described as foreign government agencies that might have some kind of a role in higher education, such as Australian Education International. The former recorded a mean of just 2.77; the latter a mean of 2.04. Both were considered somewhat irrelevant to students who made use of more direct sources such as friends who had actually studied in a foreign university environment. Secondly, government bodies were often viewed with a little suspicion in the sense that students felt that they would simply provide the "government line" on a range of educational issues. Students preferred to also go direct to foreign universities rather than deal with government agencies and bodies.

\section{Universities}

This issue was also divided into two items: the first was Hong Kong universities (included because so many foreign university programs are delivered via the 8 universities in Hong Kong); the second was foreign universities that provided the programs in Hong Kong or at home. The first scored 2.74; the latter 4.07. Students frequently consulted universities directly (often via their Internet sites, discussed below), but they did not always consult Hong Kong universities (or their education liaison and continuing education offices such as SPEED or SPACE at the Hong Kong Polytechnic University or University of Hong Kong, respectively); at least not in the initial expectation formation and building period-that is when they were seeking information that would help them to develop an initial set of expectations about a range of foreign university programs. However, when they had narrowed the field to a handful of foreign universities, they would then consult with offices such as SPACE and SPEED at the various universities to obtain further information about the specific foreign programs delivered in Hong Kong. This helped to recast and consolidate their views about the foreign university programs available in Hong Kong.

\section{Agents in Hong Kong}

This item included associations that deliver a wider range of foreign sourced programs in Hong Kong. Associations can be divided into four categories or levels ranging from large, fully fledged academic associations, such as the Hong 
Kong Management Association, to smaller bodies, which are often single room agents (Willis, 2001). This complexity was explained to students prior to completion of the questionnaire and during the focus group meetings. It was found that agents/associations-in all of their various forms and guises-scored a mean of 4.10 and were one of the key influencers on the formation of expectations in regard to foreign university programs, particularly delivered in Hong Kong via a range of modes. They influenced expectations, particularly via the heavy promotion of foreign programs and courses undertaken in the Hong Kong market. They were, however, only viewed as a conduit for foreign universities-as a way of "getting to" the foreign university for information and advice.

They could, however, impact on the formation of expectations about the foreign university, thus:

- If the association or agent was large, well established and had a sound academic reputation, a halo effect appeared to take place wherein students tended to form a very positive view and maintain high expectations about the foreign university program: in this situation, the view of the foreign university was affected by the view of the Hong Kong agent or association; and, conversely,

- If the association or agent was small and not well regarded or recognised, students tended to form a lower level of expectation about the foreign university and its programs. The exception to this was when the foreign university's image in the Hong Kong market was strong and favourable enough to overcome any concerns about the local agents. In this situation, the image of the foreign university overcame local image issues such as the relationship with the agent or association.

In summary, by and large, these bodies were considered important because they enabled students to access foreign university information and advice.

\section{Students from Hong Kong and Foreign Countries}

These two items also yielded some surprising results, in that fellow students from Hong Kong recorded a mean of just 1.95, while students from abroad were rated at a mean of 3.59, which was relatively high. This indicates that the students in this sample tended to focus on the views of foreign students (in Hong Kong or elsewhere) in developing their beliefs and attitudes about foreign universities rather than local students. This was found to be despite the fact that they would be exposed to the latter very frequently and would surely discuss these issues with them from time to time. 
However (as with the government agencies and bodies discussed above), students indicated that they preferred to talk to more direct sources of information than to (perceived) secondary sources, such as local students and government bodies. Neither of these groups were perceived to be directly and immediately linked to foreign programs and universities, and therefore lacked credibility.

\section{Schools in Hong Kong and Abroad}

Students did not rank these items highly. Local schools accounted for a mean of just 2.37, while schools abroad ranked just 2.05. This item was, however, included on the basis that there may have been some impact on the formation of views at the school level, that is prior to students entering the higher education sector. This did not prove to be the case. Once again, students indicated that they preferred to go to direct sources, such as universities themselves, or agents rather than secondary sources of information. This is perhaps surprising news for foreign universities which market directly to schools in Hong Kong in the hope that they may attract students upon graduation.

\section{Education Exhibitions in Hong Kong and Abroad}

Hong Kong has many exhibitions organised by bodies such as the British Council and IDP Australia, to name just two. Local exhibitions scored highlywith a mean value of 4.14 , compared to overseas exhibitions, which scored just 2.09. The latter was included in the survey to test whether Hong Kong students travelling overseas were affected by exhibitions in these countries, particularly the countries in which they intended to study. Such was not the case-by the time they had arrived in a foreign nation, they had made their decision. Students often indicated that exhibitions were an essential source of in-

formation about foreign universities and provided an opportunity to talk to university representatives, agents and associations directly. They also indicated that exhibitions often enabled them to form initial, basic expectations about a set of foreign universities and these views would be modified and developed over time, as they undertook more detailed research about the selected universities and organisations. This more specific formation process was undertaken primarily by visiting the organisations and/or their agents in Hong Kong, contacting the organisation if it did not have an office in Hong Kong, and visiting Web sites, as noted below. 


\section{Brochure Materials}

This section was divided into three items: brochures provided by foreign universities (mean 4.29), brochures provided by foreign governments (mean 3.80) and brochures provided by the Hong Kong Government (mean 1.90). The first was considered to be the most important and was usually obtained from local agents or other types of partners such as universities, or direct from universities overseas. Various local government publications were not used very much, as they were not considered to be as reliable as material received directly from the foreign organisation. Government publications from abroad were used to (a) obtain information about conditions abroad, and (b) to ascertain the status, level and ranking of universities in the particular foreign nation. An interesting observation was that brochure material in the foreign language was considered to be more authentic than brochures printed in the local Cantonese dialect. The exception occurred where these brochures were printed by a local association or agent, in which case they were seen to be basic summaries of foreign university programs.

\section{Advertisements}

Advertisements were tested according to the following items: foreign university advertisements (such as the many print advertisements placed in the South China Morning Post)-mean 3.72; and advertisements provided by the foreign government-mean 2.77. The latter included block advertisements sometimes inserted by foreign governments and/or their agencies promoting, for example, study abroad in England. Again students indicated that they preferred to go straight to the source-in this case, specific advertisements placed by foreign universities and their agents in Hong Kong. There was no clear preference between advertisements placed directly by foreign universities and those which were placed by agents and associations, or even Hong Kong universities on behalf of foreign universities, except that advertisements which advertised a plethora of university programs were seen to be "cheap" and of lower ranking compared to advertisements promoting a single foreign university. Advertisements, which promoted foreign universities in large type, and the Hong Kong partner in the same level of type, did not appear to cause any confusion amongst students, although, as mentioned, the status and level of the local Hong Kong partner could impact on the perceived value of the foreign university program.

Promotional material provided by agents and associations was also included, since so much information about foreign universities was channelled through local partners. This scored 3.47, which was comparatively high. 


\section{Internet Sites}

This issue was split into Internet sites provided by foreign universities (mean 4.55 ) and Internet sites provided by foreign governments (mean 3.43). The latter included sites operated by government bodies and agencies involved in the promotion of foreign education in its various guises, including on-campus delivery in a range of countries, such as Hong Kong, and study abroad. Students much preferred university sites-again, an example of going straight to the source of information-and these ranked higher than any other item in this study. Students looked for general and specific material about courses, data on costs and prerequisites (and credits/exemptions), and preferred sites that clearly identified differences between courses and programs on-campus and delivered in other modes such as distance education and in Hong Kong. They also made use of e-mail services and considered these crucial. All students visited sites more than once as they moulded their views about universities. Sites could, almost in isolation, create or destroy an image of a foreign university. More than brochure material, they helped to shape and form views and expectations about foreign universities.

\section{Other Less Direct Items}

The survey included a range of other items which were somewhat less directly related to the specific issue of foreign universities in Hong Kong. These items were designed to ascertain whether issues such as television, newspapers, fashions, and the general image of a foreign country impacted on the formation of expectations about a university. The mean scores and standard deviations are shown in Table 1.

TABLE 1. Mean Scores and Standard Deviations of Less Specific Items Measured

\begin{tabular}{|l|c|c|}
\hline \multicolumn{1}{|c|}{ Item } & Mean & $\begin{array}{c}\text { Standard } \\
\text { Deviation }\end{array}$ \\
\hline Travel Abroad & 2.68 & .81 \\
\hline Radio & 2.56 & .69 \\
\hline Fashion in Foreign Country & 2.48 & .72 \\
\hline Friends Abroad & 2.40 & .57 \\
\hline Image of Foreign Country & 2.38 & .86 \\
\hline Cable Television & 2.26 & .56 \\
\hline Television & 2.11 & .58 \\
\hline Products of Foreign Country & 2.09 & .71 \\
\hline Newspaper & 1.85 & .67 \\
\hline
\end{tabular}


It can be seen that, in all cases, the items scored low mean values. Students felt that the most crucial issues associated with forming expectations about foreign university programs delivered either in Hong Kong or in the home country of the university were related to the university itself-that is, its courses, reputation, status, ranking, research output and image. The overall image and associated aspects of the foreign country were seen to be far less important, at least in terms of the formation of expectations about the university.

\section{Conclusion to Part A (Formation of Expectations)}

The research found that the key factors which assisted in the formation of expectations were as follows:

- Foreign university Internet sites 4.55

- Exhibitions in Hong Kong 4.14

- Agents and Associations 4.10

- Foreign university brochures 4.07

- Friends studying abroad 4.07

- Friends living abroad 4.02

- Friends in Hong Kong 3.96

- Family in Hong Kong 3.93

These items can be divided three related categories:

Institutional sources: Foreign universities and their Hong Kong partners;

Marketing communication sources: Foreign university promotional material and information sources (such as brochures, Internet sites, exhibitions); and

Personal sources: including friends who had studied in foreign programs, and family.

These three categories can be summed up as sources of information and advice which most directly and specifically were of value and use to students in forming their expectations about foreign university study. Sources (items) which were less direct and clearly related to universities and personal contacts, such as those depicted in Table 1, were considered almost irrelevant: students chose to go directly to the specific sources of information and advice listed above. 


\section{Part B: Continuous Formation of Expectations}

The research found that students felt that they did review, reform, and remould their views and expectations about the university on the basis of the aspects shown in Table 2 .

As can be seen, a wide range of factors influenced students' expectations as they undertook subjects. It was quite possible for a student to have a range of expectations about each subject being studied. If enough of these subjects were below par, the overall expectation regarding the degree program was lowered. Conversely, if the majority of subjects at any given time were deemed to be of good quality the expectations of the students regarding the program as a whole was sustained or even enhanced.

TABLE 2. Summary of Factors Affecting Continuous Formation of Expectations

\begin{tabular}{|c|c|}
\hline Aspect & Discussion \\
\hline Teaching & $\begin{array}{l}\text { If the standard of teaching dropped for a particular subject, students } \\
\text { would tend to lower their expectations. According to respondents, good } \\
\text { teachers challenged their students, excited them, helped them to pass } \\
\text { the subject by giving tips, and provided clear guidelines and structure for } \\
\text { assignments and examinations. Good teachers also managed to encour- } \\
\text { age a creative and individual learning experience within a reasonably } \\
\text { structured and organised environment which to many students meant that } \\
\text { they managed to meld Chinese and foreign teaching styles. Foreign } \\
\text { teachers were a plus in terms of expectation reinforcement because they } \\
\text { were seen to be "what we are paying for" and a conduit to the West for } \\
\text { many students. }\end{array}$ \\
\hline $\begin{array}{l}\text { Subject } \\
\text { materials }\end{array}$ & $\begin{array}{l}\text { If subject materials were poor, expectations were again lowered. Good } \\
\text { learning material were those which were well written, simple in structure, } \\
\text { and easy to use. Subject books which summarised subjects were } \\
\text { particularly popular because they saved time. Material which was } \\
\text { international in flavour (rather than local to either Hong Kong or the } \\
\text { foreign country) was preferred. }\end{array}$ \\
\hline Examinations & $\begin{array}{l}\text { Examinations which had broad, simple questions were preferred to multiple } \\
\text { choice questions which were disliked, particularly if they were in English. A } \\
\text { poor (i.e., complex and unclear) examination could destroy students' } \\
\text { expectations and associated views about a subject. }\end{array}$ \\
\hline Assignments & $\begin{array}{l}\text { Once again, expectations could be raised or lowered depending on the } \\
\text { quality of assignments. Good assignments tended to be simple, precise } \\
\text { and (especially popular) detailed in terms of a possible structure for an } \\
\text { answer. Poor assignments were long and waffly. Any more than two } \\
\text { assignments per subject tended to damage the expectations of students. }\end{array}$ \\
\hline Marks & $\begin{array}{l}\text { This was a key, but certainly not the only, issue which affected } \\
\text { expectations. Low marks for an assignment, examination or the subject } \\
\text { as a whole tended to lower expectations of the program, whilst high } \\
\text { marks did not. However, this basic finding was complicated by students } \\
\text { noting that if they got a high mark for a subject because the subject was } \\
\text { "known to be easy" they would lower their expectation (and respect) for } \\
\text { the subject because it was seen to be "poor value for money." A high } \\
\text { mark for a demanding and challenging subject was deemed by students } \\
\text { to be particularly powerful in terms of enhancing their expectations of the } \\
\text { subject and the degree as a whole. }\end{array}$ \\
\hline
\end{tabular}


Therefore, expectations changed almost constantly for subjects and, to a lesser extent, for the program as a whole. At any one time, students indicated that they could feel positive about some subjects, negative about others and ambivalent (quite common) about the program as whole. Their expectations could change from week to week depending on a range of factors noted in Table 2. They all admitted that they changed their expectations constantly. This is why we have chosen to adopt the term continuous because expectation formation was a continuous process.

\section{FURTHER DISCUSSION}

There was also a definable link between the initial formation of expectations phase-part $A$, and the continuous formation of expectations phase-part $B$.

This is a two stage process which was identified through the depth interviews, as follows.

\section{The Initial Stage (Initial Formation of Expectations-Part A)}

In this stage, the students deliberately collected a wide range of data and information that enabled them to form initial, and often quite generalised, views about foreign universities. These tentative expectations and views were often formed as a result of visits to exhibitions, discussions with friends and viewing Internet sites. The views of family and friends were also important at this stage, particularly, in regard to family, in establishing broad parameters-for example in regard to study abroad compared to study in Hong Kong.

\section{The Ongoing Stage (Continuous Formation of Expectations-Part B)}

In the second stage, students would continue to remould, reform and rebuild expectations about the chosen university as they undertook their studies over a period of several years. In the case of a foreign degree program undertaken in Hong Kong, this could involve a six- to seven-year period, as students often studied part time whilst they were working. At this stage, expectations would be moulded and changed by issues experienced such as the standard of courses; whether course material was up-to-date or not; the personality of lecturers and administrative staff; the grades received for subjects, and the reputation of the university-which also might change over time. Views of their student cohort were also important in this third stage. Also, if the student was studying in the foreign country, the quality of facilities and some aspects of 
lifestyle (cost of living, friendliness of the community and ease of getting around) were also important.

These two stages can also be conceptualised in a different way; in terms of external and internal formation stages, as follows:

- The External Formation Stage: comprising the first stage described above, whereby a student formed views and expectations based on a range of information provided by organisations and people without actually experiencing the service at first hand; and

- The Internal Formation/Reformation Stage: The second stage, whereby a student enrolled in a university and undertaking studies remoulded expectations and views based on the actual experience of the service.

During this stage, the student is far more influenced by their (personal) experience of direct interaction with the service (tangible and intangible aspects) than by the (impersonal) views of external sources, such as those found at university exhibitions, Internet sites and even friends at the university. The formation process is at once more direct and more personal as the student actually experiences the service at first hand. When a discrepancy occurs between prior expectations and the actual performance of the service (which is inevitable over an extended period), a negative disconfirmation is caused, potentially leading to dissatisfaction. At this point, decisions are made to accept the situation by reforming the expectation, or rejecting the situation by withdrawing. In a high-involvement purchase situation (such as enrolment in a university program), it is more likely that expectations will be revised in order to allow continuation.

However, students noted that the external formation issues were not completely replaced-for example, students, (during the second continuous formation phase) would still be somewhat influenced by friends' views and opinions and information and image conveyed through Internet sites, but these were of lesser importance than the actual personal interaction with the service itself.

\section{Theoretical Implications}

This research contributes to the met expectations/satisfaction literature in the following ways:

- The research identifies the concept of continuous formation of expectations which is of particular relevance to educational services marketing because of the length and complexity of the service encounter; 
- The research also identifies a range of factors affecting the initial formation of expectations for foreign programs in a home market (not previously researched);

- It has been possible to link the two stages or phases;

- It has been noted that whereas the first (formation of expectations) is dominated by external factors or influencers, the second is dictated largely by the service encounter or internal issues; and

- It has been possible to indicate the complexity of the continuous formation of expectations process whereby students would change and mould their expectations depending on a variety of issues evaluated for each individual subject.

While the factors affecting formation of expectations are of value, the key value of the research is also the identification of this volatile, continuous formation process.

\section{Managerial Implications}

Implications for management include the following:

For the formation of expectations issue, foreign universities need to:

- Focus on the quality of Internet sites, exhibitions in Hong Kong, the use of agents and associations, and university brochures as some of the most important promotional and influencing tools at their command;

- Also pay attention to how they can make use of people in Hong Kong and abroad as key influencers. The use of testimonials, invitations to parents to attend information sessions, and the development of links between Hong Kong students studying in the foreign location and at home in Hong Kong would be appropriate mechanisms to help positively influence expectation formation amongst students in Hong Kong.

For the issue of continuous formation, foreign universities need to:

- Focus on issues associated with the quality of teaching, educational materials, assessment and other aspects of subject delivery to ensure, as much as possible, that quality is maintained to preserve a reasonable sense of expectations being confirmed; and

- Include in their programs in Hong Kong and elsewhere regular counselling and monitoring sessions to ensure that changing student expectations 
can be tracked and rectifying action taken to avoid undermining the overall level of expectations of a university program in the Hong Kong market.

Above all, and critically, universities must recognise that the process of expectation formation and reformation is a changing and continuous process and they need to be vigilant at all stages of delivering a university course lest they lower standards and ruin student expectations. Such a scenario could be disastrous, since this research indicates that a key source of initial expectation formations comes from students already enrolled in the program!

\section{Limitations and Future Research}

There are some limitations to this study: the fact that it was conducted in one location only (Hong Kong) and the concept of continuous formation of expectations would be usefully studied through the use of a longitudinal study. The key opportunity for further research is to evaluate the concept of continuous formation linked to more specific aspects of the service to ascertain the precise link between variations in formation expectation and "remoulding" and specific service experiences.

Nevertheless, the research as it stands is of value in two ways: it identifies the formative factors relating to the formation of expectations for foreign delivered programs in the home country (a mode of educational delivery which is becoming increasingly popular), and second, it defines and discusses the concept of continuous formation.

\section{REFERENCES}

Anderson, E.W. and V.W. Sullivan (1993), The antecedents and consequences of customer satisfaction for firms. Marketing Science, 12: 125-143.

Austin, Mark (1988), Asian electrical and computer engineers at a California university: Why are they here? Why might they stay? Santa Barbara: University of California.

Bromilow, George \& Zubrzycki, J. (1990), Our education services go to market. Australia Now, 14(1): 25-27.

Churchill, G.A. and C. Suprenant (1982), An investigation into the determinants of customer satisfaction. Journal of Marketing Research, 19: 491-504.

Harris, R. \& Moran, P. (1982), Managing Cultural Synergy, Volume Two. Houston: Gulf Publishing.

Hausler, T., Sharma, R. \& Sivagnanam (1995), Australian university experiences of fee-paying overseas students. Swinburne University of Technology, Australia.

Hoyer, W.D. and D.J. MacInnis (2001), Consumer Behaviour, 2nd ed. Houghton Mifflin Company, Boston, USA. 
Johnson, M.D. and C. Fornell (1991), A Framework for Comparing Customer Satisfaction Across Individuals and Product Categories. Journal of Economic Psychology, 12: 267-286.

Kennedy, R.E., Willis, M.K., and M. Rushdi (2000), Attractiveness of Australian Education to Foreign Students: An Empirical Study of the Match Between Foreign Students' Expectations and Experience. Proceedings of ANZMAC Conference, Queensland.

Kennedy, R.E. (2001), Paper 199 Salesforce Turnover in Australian Direct Selling Organisations. Proceedings of ANZMAC Conference, Auckland, NZ.

Kristensen, K., Martensen, A., and L. Gronholdt (1999), Measuring the Impact of Buying Behaviour on Customer Satisfaction. Total Quality Management, 10(4/5): 602-614.

Lawley, Meredith (1993), Factors influencing the choice of destination in international education: The case of Hong Kong. Mbus Thesis, University of Southern Queensland, Australia.

Lawley, Meredith A. \& Perry, Chad (1998), Thai \& Malaysian students' perceptions of overseas study destinations: An exploratory study. Department of Marketing, University of Southern Queensland.

Lewin, K. Stephens, D. \& Vulliamy, G. (1990), Doing Educational Research in Developing Countries: Qualitative Strategies. The Falmer Press, London.

Molla, Bekele \& Sedlacek, W.E. (1989), International student self-appraisal and institutional expectations. Research Report, 23, University of Maryland.

Rao, Gutta (1979), Brain Drain and Foreign Students-A study of the attitudes and intentions of foreign students in Australia, the USA, Canada and France. Brisbane: University of Queensland Press.

Solomon, M.R., Surprenant, C., Czepiel, J. and E.G. Gutman (1985), A Role Theory Perspective on Dyadic Interactions: The Service Encounter. Journal of Marketing, 49: 99-111.

Steadman, George \& Dagwell, R.H. (1990), A survey of overseas students in Queensland. Australian Universities Review, 1 \& 2: 59-63.

Stewart, Kevin, \& Felicetti, L. (1991), Marketing a public university to international students. Journal of Professional Services Marketing, 7 (1): 67-74.

Tannenbaum, Scott I., John E. Mathieu, Eduardo Salas \& Janis A. Cannon-Bowers (1991), Meeting trainee's expectations: The influence of training fulfillment on the development of commitment, self-efficacy, and motivation. Journal of Applied Psychology, 76(6): 759-69.

Wanous, John P., Timothy D. Poland, Stephen L. Premack \& K. Shannon Davis (1992), The effects of met expectations on newcomer attitudes and behaviours: A review and meta-analysis. Journal of Applied Psychology, 77(3): 288-97.

Wilkinson, J.W. (1995), Marketing Australian universities to overseas students. Asia-Australia Marketing Journal, Vol. 1 pp. 71-78.

Willis, M. and M. Rushdi (2000), An Identification and Analysis of Students' Expectations and Views Regarding Foreign Sourced Tertiary Education Programs Delivered in China: Investigating the Next Stage of Internationalisation and Market Entry for Foreign Universities. Proceedings of the ANZIBA Conference, Auckland, New Zealand.

Willis, Mike (1999), Paper 281, An examination of agreements between Chinese State and Foreign universities as an indicator of the changing nature of Sino-Foreign ser- 
vice industry cooperation. Proceedings of the Australian and New Zealand Marketing Academy Conference (ANZMAC), Sydney.

Willlis, Mike (2000(a)), The development of a specific and structured market entry model for use by Foreign universities wishing to establish cooperative programs with Chinese state universities and/or institutes for a range of collaborative activities, Proceedings of the WTO \& Sino-Australian Economic/Education Cooperation Conference, sponsored by Tongyi University and Latrobe University, Shanghai, pp. 100-152.

Willis, Mike (2000(b)), Adding competitive value to Chinese state universities-one key to market success for foreign universities in China, Proceedings of the WTO \& Sino-Australian Economic/Education Cooperation Conference, sponsored by Tongyi University and Latrobe University, Shanghai, pp. 93-100.

Wu, W.C. (1989), Strategy Formulation in the International Services Sector: Factors Influencing Students' Perceptions of College Recruiting Activities, PhD Thesis, University of Mississippi.

Zeithaml, V.A, Parasuraman, A. and L.L. Berry (1993), The Nature and Determinants of Customer Expectations of Service, Marketing Science Institute Research Program Series, May, Report No. 91-113.

Received: 03/19/01

Revised: 04/26/01

Accepted: 02/05/03 
APPENDIX

Descriptive Statistics Summary Data

\begin{tabular}{|c|c|c|c|c|c|}
\hline & $\mathrm{N}$ & Minimum & Maximum & Mean & Std. Deviation \\
\hline Foreign university Internet sites & 97 & 3 & 5 & 4.55 & .60 \\
\hline Brochures provided by foreign universities & 97 & 3 & 5 & 4.29 & .63 \\
\hline Educational exhibitions in $\mathrm{HK}$ & 97 & 1 & 5 & 4.14 & .84 \\
\hline Education agents in $\mathrm{HK}$ & 97 & 2 & 5 & 4.10 & .60 \\
\hline Friends who have studied abroad & 97 & 3 & 5 & 4.07 & .53 \\
\hline Foreign universities & 97 & 3 & 5 & 4.07 & .56 \\
\hline Friends abroad & 97 & 2 & 5 & 4.02 & .52 \\
\hline Friends HK & 97 & 3 & 5 & 3.96 & .61 \\
\hline Family HK & 97 & 1 & 5 & 3.93 & .82 \\
\hline Family abroad & 97 & 1 & 5 & 3.87 & .76 \\
\hline $\begin{array}{l}\text { Brochures provided by foreign } \\
\text { government }\end{array}$ & 97 & 2 & 5 & 3.80 & .76 \\
\hline $\begin{array}{l}\text { Advertisements by foreign } \\
\text { universities }\end{array}$ & 97 & 2 & 5 & 3.72 & .49 \\
\hline Students from foreign universities & 97 & 3 & 5 & 3.59 & .55 \\
\hline $\begin{array}{l}\text { Promotional material prepared by } \mathrm{HK} \\
\text { educational agents }\end{array}$ & 97 & 2 & 5 & 3.47 & .56 \\
\hline $\begin{array}{l}\text { Internet sites provided by foreign } \\
\text { governments }\end{array}$ & 97 & 1 & 5 & 3.43 & .66 \\
\hline Siblings who have studied abroad & 97 & 2 & 5 & 3.11 & .61 \\
\hline Government bodies in HK & 97 & 1 & 4 & 2.77 & .62 \\
\hline $\begin{array}{l}\text { Advertisements by foreign } \\
\text { governments }\end{array}$ & 97 & 1 & 4 & 2.77 & .53 \\
\hline HK universities & 97 & 1 & 5 & 2.74 & .70 \\
\hline Travel & 97 & 1 & 5 & 2.68 & .81 \\
\hline Radio programs & 97 & 2 & 4 & 2.56 & .69 \\
\hline Fashions of the foreign country & 97 & 1 & 4 & 2.48 & .72 \\
\hline Friends who have travelled to a foreign country & 97 & 1 & 4 & 2.40 & .57 \\
\hline Image of the foreign country & 97 & 1 & 4 & 2.38 & .86 \\
\hline Schools in Hong Kong & 97 & 1 & 5 & 2.37 & .67 \\
\hline Cable TV services & 97 & 1 & 4 & 2.26 & .56 \\
\hline Colleagues at work & 97 & 1 & 4 & 2.21 & .74 \\
\hline TV programs & 97 & 1 & 4 & 2.11 & .58 \\
\hline Educational exhibitions abroad & 97 & 1 & 5 & 2.09 & .75 \\
\hline Products of the foreign country & 97 & 1 & 3 & 2.09 & .71 \\
\hline Schools abroad & 97 & 1 & 5 & 2.05 & 1.11 \\
\hline Government bodies abroad & 97 & 1 & 5 & 2.04 & .76 \\
\hline Students from HK universities & 97 & 1 & 4 & 1.95 & .77 \\
\hline $\begin{array}{l}\text { Brochures provided by HK } \\
\text { Government }\end{array}$ & 97 & 1 & 5 & 1.90 & .84 \\
\hline Newspapers & 97 & 1 & 4 & 1.85 & .67 \\
\hline
\end{tabular}


Copyright of Journal of Marketing for Higher Education is the property of Haworth Press and its content may not be copied or emailed to multiple sites or posted to a listserv without the copyright holder's express written permission. However, users may print, download, or email articles for individual use. 